\title{
Cumplicidades entre mídia e audiência nas narrativas de "real" na ficção e no jornalismo
}

\author{
Fabiana Piccinin ${ }^{1}$
}

\begin{abstract}
Resumo: Este artigo propõe uma reflexão sobre as reconfigurações observadas nas relações entre mídia e audiência a partir das novas possibilidades interativas oportunizadas pelas tecnologias comunicacionais, bem como a especificidade das narrativas resultantes destas relações entre os mundos da produção e do consumo dentro do circuito comunicacional. A partir da complexificação das relações entre emissor e receptor, objetiva-se, assim, pensar particularmente como as narrativas audiovisuais, neste caso, enquanto frutos do seu tempo, reorganizam suas gramáticas e linguagens no contemporâneo, em direção à aproximação a seus públicos, adotando como estratégia a oferta de sentidos como a autenticidade do narrar e a redução das artificialidades dos seus conteúdos. Para tanto, parte-se da ideia de que as mídias apostam nas narrativas que tratam do "real", a partir de uma estética pautada pela informalidade e espontaneidade, buscando de algum modo, estabelecer um contrato de cumplicidade com as audiências. Do ponto de vista metodológico, a questão é proposta em termos teóricos a partir do debate acerca da narrativa e das narrativas audiovisuais, na ficção e não ficção, além de explorar conceitualmente as interações entre emissor e receptor. Como recorte empírico, são tomados para análise exemplos de produções como documentários, séries e filmes.
\end{abstract}

Palavras-chave: Narrativa Audiovisual; Real; Interações Emissor e Receptor

Abstract: This article suggests a reflection on the re configurations observed in the relations between media and audience from the new interactive possibilities offered by communicational technologies, as well as the specificity of the narratives resulting from these relations between the worlds of production and consumption within the communication circuit. From the complexity of the relations between the emitter and the receiver, the objective is to think in a particular way on how audiovisual narratives, in this case, a result of the time, reorganize their grammars and languages, in the contemporary, towards the approach to their public, adopting as a strategy the offer of senses as the authenticity of narrating and the reduction of the artificialities of its contents. To do so, it is based on the idea that the media bet on the narratives that deal with the "real", from an aesthetic grounded on informality and spontaneity, trying to, somehow, establish a contract of complicity with the audiences. From the methodological point of view, the issue is proposed in theoretical terms from the debate about narrative and audiovisual narratives, in fiction and nonfiction, in addition to exploring conceptually the interactions between emitter and receiver. As an empirical cut, documentaries, series and films were analyzed as examples of such productions that present this "real" narrative.

Keywords: audiovisual narrative, real, emitter and receptor interactions

1 Doutora em Comunicação Social (PUC-RS). Professora e pesquisadora do Departamento de Comunicação Social do Programa de Pós-Graduação Mestrado e Doutrado em Letras (UNISC-RS). E-mail: fabi@unisc.br. 


\section{Narrativas do pós-moderno}

A estreita relação entre a experiência do viver e sua natureza narrativa funda grande parte dos conceitos a respeito do narrar, desenvolvidos por pensadores alinhados à perspectiva de que é indissociável da condição humana. A ideia, portanto, de que a narrativa, a partir do que se conhece como o movimento da virada linguística [1] é, sobretudo, este exercício de nomear o real continuamente para entendê-lo, posto que empalavrar é a forma de conhecer e apreender o mundo (MOTTA, 2013). Também Stubblefield [2] (2000) ajuda a pensar a narrativa como chave hermenêutica e epistemológica quando diz que somos únicos justamente pela habilidade em criar narrativas e pelo grau em que confiamos nelas para organizar nosso conhecimento sobre o mundo.

Em razão disso, as reflexões sobre a narrativa contemporânea requerem a compreensão de que narrar é significante e significado do espírito de um tempo (BARTHES, 2008). Ou por outra, conforme reflexões já travadas anteriormente (PICCININ, 2012; PICCININ, 2013; PICCININ \& SOSTER, 2016), as formas e os conteúdos das narrativas são estabelecidos em relação direta com seu contexto sócio-tecno-discursivo, posto que são em suas práticas, operações e formatos, traduções e interpretações de seus períodos. No dizer de Scholes e Kellog (1977, p. 47), "toda época e cultura têm suas formas narrativas".

Assim, cabe pensar neste sentido, em termos do cenário pós-moderno e da arquitetura e configurações desenhadas, como estes vão incidir na anatomia das narrativas que lhe são correspondentes. Para fazer esse olhar para a anatomia das narrativas, é preciso assumir, por princípio, o contemporâneo como este tempo em que as vigorosas epistemologias da Modernidade e suas crenças na capacidade de explicar a realidade objetivamente, e dar a ela respostas totalizantes, são gradativamente substituídas pela relativização das grandes verdades. Do ponto de vista do discurso, a contemporaneidade traz, segundo Lyotard (2004), o fim das grandes metanarrativas e da linearidade do discurso fundamentado na racionalidade que sustentaram a crença nas potencialidades da ciência e de suas descobertas e avanços em relação aos desafios apresentados pela experiência moderna. Para Jaguaribe (2007), significa dizer que há um desencantamento resultante deste reconhecimento de que a ciência já não consegue mais dar conta dos grandes desafios sobre o significado da experiência.

Ruiz (2003) também aponta para a insuficiência das explicações científicas e do papel da racionalidade, frutos de um cansaço existencial e dos efeitos da raciona- 
lização exagerada que, por sua vez, vão promover a emergência de sentidos e valores agora orientados pela ideia da liquidez. Segundo apontam Bauman (2001) e Santaella (2007), a metáfora dos líquidos bem explica este tempo porque diz respeito às ideias e conceitos que, ao abandonar sua rigidez conceitual, tornam-se fluidos, adaptáveis, assumindo os contornos das formas e suportes que passam a ocupar.

Essa dinâmica, portanto, incide na promoção de novos desenhos e gramáticas narrativas que passam a estar menos comprometidas com gêneros, classificações e contratos interacionais fixos. Apresentam-se por meio de reciclagens das intrigas ficcionais, agora recriadas para circular por várias e diferentes plataformas midiáticas e mediantes novas condições interativas. A força da hibridação da narrativa e dos papeis de seus atores como expressão do pós-moderno põe em evidência a racionalização imaginária, como diz Ruiz (2003), combinando elementos do passado mais remoto, místico e nostálgico com as influências racionais modernas.

As narrativas, portanto, que se apresentavam identitariamente em formatos definidos e delimitados, agora caminham nessa interlocução e (MURRAY, 2003) multiplicidade de argumentos ou jogos de linguagem (GRANDIM, 2015), resultando na emergência de discursos paralelos, simultâneos e multiformes, desfrutados também por novos protocolos entre seus agentes. Passam a se estruturar justamente na "mistura e combinação" de uma narrativa pela outra, permitindo que se tenha ao mesmo tempo, múltiplas e contraditórias alternativas aos pontos de vista do enredo.

Em razão disso, diz Figueiredo (2010) que, diferentemente das categorizações estabelecidas na Modernidade, cada vez mais o texto vai deixando de ser considerado uma obra fechada em si, no contemporâneo, para ser visto a partir das narrativas e das suas conexões possíveis, mediante uma ampla rede formada por inúmeros outros textos e agentes. Sem limites rigorosos e sobretudo, antigas verdades categóricas como sustentação, os conceitos e as expressões evidenciadas nas narrativas que lhes correspondem, se expandem, se recombinam e, sobretudo, se relativizam, constituindo novas configurações em seus conteúdos e protagonistas. E, em última análise, relativizando também as posições de narradores e narratários. Ou seja, os formatos e relações dinâmicas e flexibilizadas organizam novas condições que, além de erodir as verdades absolutas que fundaram as classificações de gênero, também relativizam os lugares antes fixos de emissores e usuários. E vão propondo, dessa forma, mais simetria e mais fluidez a seus conteúdos e às performances de seus agentes, prometendo, finalmente, um encontro de menos distância entre quem narra e quem escuta a partir do processo interacional daí surgido. 


\title{
Narrativas interacionais e circulação
}

Para Braga (2007), as transformações resultantes das inovações tecnológicas, capazes de ofertar novas possibilidades interativas, vão incidir diretamente nas gramáticas de formas narrativas entre as mídias e as audiências. As mudanças oportunizadas pelos novos gagdtes comunicacionais vem produzindo revisitas às relações entre os pólos da emissão e da recepção na medida em que vem se apresentando mais e mais complexificadas e reconhecidas para além da ideia de intervalo comunicacional. É dizer que, a estrutura rizomática da internet vai, assim, mostrando a sintonia com os valores e a estética contemporâneos, na medida em que promove a substituição da perspectiva linear e hierárquica pela descentralização e complexidade dos processos. Como diz Musso (2010), apresenta-se numa dinâmica de fluxos e de circulação generalizada. Ou ainda, nas palavras de Stubblefield:

\begin{abstract}
Desde que os seres humanos começaram a esculpir histórias da caça nas paredes das cavernas, através das histórias de Homero e da Bíblia, até os dias de hoje, as narrativas compartilhadas têm desempenhado um papel central na determinação de quem pertence a uma comunidade e na definição dos padrões segundo os quais essas pessoas se comportam e interagem. Mais recentemente, temos evidências de que a estrutura narrativa forma as interações de pessoas em ambientes virtuais [3]. (STUBBLEFIELD, 2017, p.1)
\end{abstract}

As narrativas, assim, por extensão, vão sofrendo alterações que ressignificam as os protocolos estabelecidos entre as mídias e suas audiências na atuação em rede onde as chances de conexões interacionais vão ganhando contornos alargados. Conforme Santaella (2007), é próprio da tecnologia criada e distribuída digitalmente, potencializar a configuração informacional em rede e permitir que as mídias cheguem aos seus públicos, obtendo destes um retorno imediato. Dessa forma, as narrativas que se auto constroem e reconstroem enquanto frutos de seu tempo, fazem mesclar também os papeis do narrador e do narratário, resultando num movimento que tende à "redução da distância entre o palco e a plateia" (FIGUEIREDO, 2010). Trata-se de um sentido de proximidade e/ou facilidade de acesso ao "Outro" que, como propõe a psicanálise, é sempre agente importante de estruturação e regulação da ação do indivíduo.

Nesta simulação e promessa de proximidade, desmitifica-se esse grande "Outro", porque mais acessível em termos do intercâmbio narrativo, oportunizado pelas novas tecnologias. Para Parente (2004), as realidades virtuais potencializam essa 
ideia de acesso ao Outro porque se apresentam por aproximação ao “(....) espaço da justaposição do próximo e do longínquo, do simultâneo" (2004, p. 100). Na esfera midiática, os mundos da emissão e da recepção se ajustam às novas possibilidades de sociabilidade interativa no âmbito da rede e suas ferramentas em uma perspectiva de planificação de suas posições.

Também Weisberg (2010) considera que, embora a rede não dissolva a noção de lugar, há um retrabalho operado na mistura da presença física e na pluripresença mediatizada. Por consequência, é a arquitetura da internet que, ao propor a circularidade comunicacional dessas trocas, oferece a suavização das dicotomias emissor-receptor, resultando no sentido de "aplainamento" das relações. Sem pontos de hierarquia, o desenho rizomático sinaliza para a transparência e "autenticidade" das narrativas, pretendendo reduzir as mediações entre narrador e narratário e buscando uma possibilidade dialógica maior, que dá à recepção um lugar para além da mera passividade. Ainda que esse agir esteja submetido às regulações e normas controladas pela emissão.

Musso (2010) diz que uma das fontes das quais a rede obtém dinamismo é justamente o desejo e a suposta oferta de uma comunicação transparente, em que os atores dominem, ao mesmo tempo, a informação e a mídia que a faz circular. Para o autor, as inovações tecnológicas e interacionais buscam:

Fazer de cada ator tanto um receptor quanto emissor: (...) o objetivo de supressão dos intermediários se transforma, conforme seu próprio movimento, em criação de uma nova camada de mecanismos mediadores que automatizam a mediação. (MUSSO, 2010, p. 123).

Neste sentido, a técnica representaria o papel de prótese na medida em que as possibilidades interativas ofertadas pelas novas tecnologias comunicacionais estabeleceriam um lugar de vínculo social, enquanto ferramentas para uma nova "democracia eletrônica”, direta, interativa e instantânea entre as mídias e suas audiências (MUSSO, 2010). Esse movimento que não é novo, vem sendo observado com mais evidência a partir da crise da representação, como bem aponta Figueiredo (2010) quando, ao assumir a impossibilidade do registro objetivo, reafirmou-se a autenticidade das narrativas mediante a busca pela equiparação entre quem narra e quem escuta justo porque a oferta tecnológica constrói este sentido de relativização e consequente aproximação entre emissor e receptor.

Por conta disso, o desenho das narrativas midiáticas e a relação destas com 
seus públicos vai permitir e pressupor apropriações destes em relação ao mundo da produção. Considera-se, portanto, que as manifestações das audiências vão pautando a dimensão da produção desde o planejamento das ofertas de suas narrativas até a entrega final, instituindo um circuito de circularidade (BRAGA, 2007) contínua. Ou seja, o monitoramento, escuta e incorporação dos discursos das audiências a partir da emissão são, sobretudo, estratégias de fidelização das mídias em relação a seus públicos que compõem um conjunto de esforços das mesmas em atender ao desejo de aproximação e cumplicidade dos dois polos, até então, dicotômicos e distantes.

Para Fausto Neto (2012), este momento em que se passa a olhar para emissores e receptores não mais como instâncias separadas pela clivagem relacional, apresenta as bases para a compreensão do mesmo como zona de contato, entendida no âmbito da própria circulação midiática. Segundo o autor, este encontro emerge com vigor em termos contratuais contemporâneos:

A complexificação tecnológica expõe o trabalho da circulação, muda os ambientes, as temporalidades, as práticas sociais e discursividades, os processos, o status dos sujeitos (produtores e receptores), as lógicas de contatos entre eles e os modos de envio e reenvio entre eles diluindo fronteiras outrora cristalizadas, em favorecimento desta nova "zona de contato", mas também de indeterminações. (FAUSTO NETO, 2012, p. 65)

Assim, vê-se que as interações estabelecidas entre narradores e narratários se constroem por meio da circulação, entendidas, portanto, não só mais como lugar de passagem, mas como um lugar de reconhecimento "(...) dos desvios produzidos pela apropriação". (BRAGA, 2012, P. 39). Para o autor, a circulação é "transformada em lugar no qual produtores e receptores se encontram em jogos complexos de oferta e reconhecimento" que demandam, em suas gramáticas de reconhecimento um esforço por parte do mundo da produção em, a partir da escuta, ofertar estes dizeres em devolutivas. Braga (2012) chama atenção para o fato de que a produção precisa estar atenta para o que chama de "fluxo adiante", reconhecido nas manifestações dos usuários frente aos conteúdos ofertados. Tanto individualmente quanto de maneira mais "coletiva", ainda que não organizada, esses narratários se emancipam da condição exclusiva a quem a mensagem era endereçada até então, ao se enxergarem em posts e comentários como integrantes de uma "comunidade" estabelecida pela audiência ao mesmo programa (PICCININ, 2016).

Estas duas grandes dimensões do circuito comunicacional produzem, segundo o autor (BRAGA, 2012), momentos dialógicos "especializados" em fluxo contí- 
nuo que justificam o esforço das mídias ao buscar sofisticar os protocolos de contato com as audiências e estabelecer relações progressivamente mais próximas e diretas. Definitivamente, neste contexto, os produtos midiáticos se constroem, não mais em razão de si, mas também de seu entorno, visto em boa parte pelo que dizem e pelo o que seu dizer produz em termos do fluxo adiante. A conexão com a audiência leva ao apuro na escuta dos retornos para atendimento de suas demandas porque, ao fim, a emissão precisa manter o controle nessa mesa de negociação comunicacional.

\section{Circuitos e narrativas de real na hiperTV}

Operacionalmente, portanto, também as narrativas em áudio e vídeo põem atenção às demandas das audiências, estruturando-se e lançando mão de estratégias para convocar e se aproximar de seus públicos. Valem-se, dessa forma, das inovações tecnológicas para impulsionar os diálogos com os receptores a partir das ofertas de seus conteúdos em uma lógica comunicacional que prevê inclusive a oferta dos recursos de escolhas do que ver, quando ver e como ver.

As zonas de contato se sofisticam para manter a sintonia com as audiências por meio de seus movimentos operados no consumo audiovisual. Como diz Musso (2004), a rede centrada no internauta resulta na valorização do individual. E aponta como exemplo os programas de televisão que investem na personalização da informação em que as audiências constroem a seleção do que querem ver e saber em termos de conteúdo, além de poderem usufruir daqueles conteúdos nas formas que melhor entenderem e quando e quantas vezes lhes for mais conveniente:

(...) o surgimento no cenário audiovisual de novos protagonistas, os interatores, está forçando mudanças cada vez mais radicais em direção a modelos de conteúdo que possam ser buscados a qualquer momento, em qualquer lugar, fruídos de maneira como cada um quiser e abertos à intervenção ativa dos participantes. Este novo tipo de consumidor/produtor está exigindo experiências midiáticas de uma mobilidade mais fluída, formas de economia mais individualizadas, que permitam a cada um compor suas próprias grades de programas e decidir de maneira particular de como vai interagir com elas. (MACHADO; VELÉZ, 2014, p. 55 - 56).

A televisão que opera nessas condições é entendida, na denominação defendida por Carlón (2014), como a TV da terceira idade, na qual a alteração radical da lógica da oferta de conteúdos fixos na grade de programação e próprios da Tv massiva operada pelo sistema broadcasting é substituída pela Tv orientada para o funcionamento em termos de fluxo de conteúdos. Ou como diz Scolari (2014, p. 45), "Os pro- 
gramas da hipertelevisão adaptam-se a um ecossistema midiático no qual as redes e interações ocupam um lugar privilegiado e adotam algumas características relevantes das "novas mídias"”. Para Tellería (2010), na hipertelevisão, parte-se do sistema broadcasting que vinculava a programação à emissora agora em direção a novos conteúdos e configurações narrativas disto decorrentes:

A dissolução do vínculo entre o conteúdo e apoio, que tinha sido a base para a definição de gêneros e formatos, atinge o seu pico com a expressão dos modelos de distribuição com base em serviços de armazenamento e sincronização de nuvem. $\mathrm{O}$ ambiente móvel é, em essência, um dispositivo multi um, cujo núcleo encontra-se sobre a concepção de modo de acesso e consumo do conteúdo e serviços. (TELLERIA, 2015, p. 206)

Por conta disso, no novo modelo de oferta das narrativas audiovisuais, abandona-se a ideia axiomática de grade de programação fixa em uma estrutura horizontal - com dia certo para exibição - e vertical - com horário também determinado - da TV broadcasting para uma outra estrutura de funcionamento marcada pela ideia de rede, em que o consumo desse produto pode se dar conforme a demanda de seus usuários. Neste contexto, seja na tela convencional, no computador ou ainda nos dispositivos móveis, pode este telespectador estabelecer relações diferenciadas de serviços com os conteúdos como por exemplo, assisti-los de modo tradicional conteúdos disponíveis na rede, desfrutando destes em uma lógica de tempo e espaço muito própria, além de poder retê-los e ainda compartilhá-los.

Assim, como na hipertelevisão não existe mais um mordomo eletrônico que convoca audiências para a programação em dia e horário fixos, as mídias, que dependem de um certo protagonismo do público na decisão de buscar assistir quando e como, apostam para tanto, na oferta e fruição personalizada do conteúdo. Para tanto, uma das estratégias de convencimento diz respeito ao investimento em discursos que ofertem o sentido de transparência e cumplicidade para, assim, produzirem efetiva vinculação entre as duas dimensões. Buscam fortalecer as zonas de contato, apresentando narrativas que mostram uma ligação muito estreita entre o narrar e o mundo empírico, como sintoma da necessária desconstituição dos artifícios exigida por este processo de autenticação do dizer.

Dessa forma, a dinâmica da hipertelevisão objetiva acionar a energia deste usuário, seduzindo ao consumo de seus conteúdos - que dele depende em boa parte - ao encantá-lo com narrativas que prometem a redução das mediações e dos artificialismos do narrar. Aposta em razão disso, nas narrativas de "real" para buscar seus 
públicos, acreditando na força de sedução destes temas, conforme apontam Jaguaribe (2007) e Zizek (2003), por conta da "paixão pelo real" que se experimenta contemporaneamente, como reação aos excessos da virtualização pós-moderna. São narrativas que tratam da temática do real, por meio da oferta de um sentido de autenticidade, capazes de produzir efetiva identificação com as audiências cansadas das pirotecnias audiovisuais. E que decorrem não só das histórias contadas, mas também da linguagem adotada a partir do "não tratamento" e da "ausência da pós-produção" da narrativa. Quanto mais "cru”, árido e, por vezes brutal, mais o real trazido na narrativa audiovisual é capaz de instituir o sentido de espontaneidade e de redução dos artificialismos pretendido junto a seus públicos, por meio de personagens humanizados e de intrigas capazes de serem traduzidas nas linguagens adotadas como "provas de verdade", como dizem Margato e Gomes (2012). Ou como diz Jaguaribe (2007), o destaque se dá ao que é menos intermediado porque coloca o público diante da brutalidade do real.

A hipertelevisão, portanto, alinha-se à performance do conjunto midiático porque oportuniza que a confiabilidade ao ato de enunciação seja dada conforme a estratégia da emissão, tanto pela sua temática do real quanto em sua promessa de gradativa diluição das fronteiras entre seu dizer e suas audiências, convencendo-as deste lugar de mais cumplicidade e, eventualmente, protagonismo e empoderamento. Também para Lipovetsky e Serroy (2009) a redução desse hiato entre a emissão e suas audiências conotada nas narrativas de real instaura um efeito de cumplicidade, fundado sobre uma cultura de imagens e arquétipos compartilhados. Neste contexto, o real "verdadeiro" está por oposição ao artificial e suas mediações como diz Calabrese (1999), porque é capaz de produzir a ilusão da visibilidade. A "verificabilidade” dos eventos, diz o autor, é característica da idade neobarroca, este tempo em que as novas tecnologias vão estabelecendo uma relação direta com a insuficiência na confiança do real ofertado.

Figueiredo (2010, p. 3) lembra que a credibilidade do relato “(...) não é conferida pela objetividade ou transparência do discurso do narrador-intelectual, mas, ao contrário, pela ênfase no lugar de onde se fala, procurando-se também, deixar claros os recursos utilizados no registro (...). Por consequência, observa-se a emergência de relatos, por exemplo, centrados no "eu" enquanto um narrador que atesta, por seu protagonismo, a veracidade e intensidade do vivido que fala para um "você", receptor.

Nas artes, a autoreferrência surge com a recorrência às autoficções, por exemplo, onde autor e narrador se confundem na mesma cena e o traço autobiográfico traz um pressuposto de verdade. No audiovisual, embora as indexações sejam discutí- 
veis contemporaneamente, em razão sobretudo das recombinações narrativas que as novas configurações sócio-técnico-discursivas vão instaurando, como vem se tratando nesta reflexão, valem para as referências que se quer fazer quando se fala, também a título de exemplo, dos documentários. São produções personificadas, muitas vezes, na figura de um apresentador protagonista que narra e experiencia o que mostra, nos moldes de Michael Moore, para ficarmos em uma citação ilustrativa. Ao estabelecer estes novos protocolos narrativos, o jornalismo audiovisual aliás, vai rompendo com o contrato que vinha embasando sua prática desde então, dissimulada nos princípios da "imparcialidade e objetividade dos fatos", pondo-se em direção agora à autoralidade da narrativa (PICCININ; ETGES, 2014).

É, portanto, repórter e ator da enunciação aquele que testemunha e narra essa experiência, nos moldes do que propõe Santiago (2002) quando trata do narrador pós-moderno. Movimento comum nas reportagens e programas televisivos jornalísticos que adotam uma estética própria dos reality shows, em que, atoralmente, atesta-se o fato por vivê-lo e falar dessa vivência, incluindo aí os próprios processos de confecção da narrativa. Além deles, documentários, programas de reportagem, filmes e séries se endereçam às suas audiências pautando seus conteúdos no âmbito das redes sociais ainda antes de seus lançamentos para, preliminarmente, construírem suas comunidades de recepção em acordo com o que diz Jenkins (2014) quando fala das características da transmídia. A narrativa não está, portanto, somente no filme, mas nos diferentes suportes que as novas possibilidades tecnológicas lhe ofertam. Uma vez no cinema ou nos portais de conteúdo, as audiências fazem suas devolutivas, manifestam suas considerações a respeito, gerando o "fluxo adiante" nos dispositivos que lhe são permitidos e por meio do qual as mídias procuram manter-se continuamente sintonizadas.

No caso dos documentários e programas jornalísticos, estes tendem nesse esforço pela oferta do real mais real do que o real, paradoxalmente, a ficcionalizar-se para capturar esse público, como por exemplo no metanarrativo documentário "Jogo de Cena" (2007), em que Eduardo Coutinho ironiza, por vezes, as próprias fronteiras do fático e do ficcional. Ou em "O prisioneiro da grade de ferro" (2004), em que Paulo Sacramento traduz o acesso à verdade no fato de as câmeras serem operadas pelos próprios prisioneiros.

Em programas de reportagem como "Profissão Repórter" e "A liga” (PICCININ, 2013) observa-se, além da estratégia narrativa de autenticação do relato via performance do jornalista-ator, também a eliminação da bancada e do estúdio, a adoção 
do plano sequência e o privilégio das sonoras por oposição ao off que combinam com a ideia de "edição mínima" ou "não edição" do produto audiovisual como esforço de redução dos artificialismos. Já na ficção audiovisual, por sua vez, o narrador protagonista se autoreferencia brincando com os próprios limites já há tempos insuficientes entre o fático e o não fático ao se mostrar mais próximo de seu narratário.

Na ficção audiovisual, além de explorar as possibilidades que a transmídia oferece para criar as comunidades de fanfiction, as séries e filmes tratam de buscar manter esse contato ao oferecer narrativas, com frequência, baseadas em histórias reais. E marcadas, entre outros, pela humanização da personagem que, nem assume lugar de destaque como na hierarquia narrativa de outrora, nem se apresenta em um traço único e idealizado da psique, diferentemente da prática romântica moderna. Nem boazinhas, nem mázinhas, mas humanas ou complexas (FORSTER, 1969), as personagens apresentam dramas reais, ordinários e cotidianos, capazes de produzir a adesão dos públicos pela identificação gerada.

Neste sentido, nas séries que precisam continuamente lidar com a manutenção do contato com os usuários em termos do consumo estabelecido através dos portais de conteúdo, a narrativa precisa de fato buscar a vinculação a cada episódio de modo que garanta a volta ao contínuo da história. Em "House of Cards", por exemplo, a estratégia foi descontruir o conceito canônico de quarta parede (STEINDORFF, 2015) para envolver o espectador nas artimanhas do narrador, investindo na cumplicidade gerada por este movimento entre narrador e narratário. A troca de confidências entre o narrador protagonista e seus narratários contribui decisivamente para a adesão à série, atualmente uma das mais premiadas da produção audiovisual do segmento.

Em todas estas produções, as intenções da emissão em se aproximar das audiências parecem se efetivar na medida em que conseguem de fato a mobilização dos públicos pela força, sobretudo, da boa narrativa que, como diz (STUBBLEFIELD, 2000) continuará a desempenhar um papel central na organização das comunidades virtuais. Para o autor

"O desafio para designers e teóricos da comunidade virtual consiste em compreender a forma como mudar nossa compreensão da estrutura narrativa e alterar essas histórias. Mudança que significa, por sua vez, nossa compreensão de comunidade, sociedade e ser humano. (STUBBLEFIELD, 2000, pág. 4). 


\section{Considerações Finais}

A reflexão esboçada neste artigo parte da ideia da ideia de que as narrativas estabelecem uma relação de forma e conteúdo em acordo com o contexto sócio-técnico-discursivo em que estão inseridas. Neste sentido, pode-se dizer que, no âmbito da dimensão societária, é o pós-moderno e suas formas e reformas contínuas no espírito da liquidez que vai pautando a relação das narrativas entre si e com os usuários. Este movimento se reforça pelas condições tecnológicas ofertadas no contemporâneo, posto que a atuação em rede põe ênfase na descentralização e na tendência à planificação das relações entre os conteúdos narrativos das diferentes mídias e destas com seus públicos. Ou seja, menos mediação e mais proximidade que, por fim, no discurso se manifesta no consumo personalizado sob demanda em termos da forma da estrutura organizativa da narrativa, e de conteúdo na aposta ao sentido de proximidade possível que as narrativas de real são capazes de oferecer e produzir identificação e vinculação. Os heróis das histórias contemporâneas são aqueles frutos de uma construção de sentido, a partir da qual, cada um pode se reconhecer em sua condição ordinária, cotidiana e, portanto, verossímil. E, aos quais se pode ter acesso na suposta quase simetria de lugares hoje ocupados entre quem narra e quem escuta dentro do circuito comunicacional.

\section{Notas}

[1] A virada linguística foi uma mudança de paradigma na filosofia ocidental ocorrida durante o século XX, que retira o foco de preocupações da metafísica para colocá-lo na linguagem e nas relações estabelecidas com as humanidades. Isto porque a filosofia passa a tomar como importante em suas reflexões a busca pelo significado, entendendo que, para tal, é preciso assumir que nada existe fora da linguagem (MOTTA, 2013).

[2] We are unique, both in our ability to form narratives, and in the degree with which we rely upon narratives to organize our knowledge of the world. (STUBBLEFIELD, p. 1)

[3] Since human beings began carving stories of the hunt on cave walls, through the stories of Homer and the Bible, to the present day, shared narratives have played a central role in determining who belongs in a community, and in setting the patterns according to which those people behave and interact. More recently,we have evidence that narrative structure informs the interactions of people in virtual environments.

\section{Referências}

BARTHES, Roland et al. Análise estrutural da narrativa. 5. ed. Petrópolis: Vozes, 2008.

BAUMAN, Zygmunt. Modernidade líquida. Rio de Janeiro: Zahar, 2001.

BRAGA, José Luiz. Mediatização como processo interacional de referência. In: MÉDO- 
LA, Ana Silvia, ARAÚJO, Denize Correa e BRUNO, Fernanda (orgs.). Imagem, visibilidade e cultura midiática. Livro da XV Compós. Porto Alegre: Sulina, 2007.

BRAGA, José Luís. Circuitos versus campos sociais. In: JANOTTI JUNIOR, Jeder; MATTOS, Maria Ângela; JACKS, Nilda. (orgs.). Mediação e Midiatização. Salvador: UFBA: Brasília: Compós, 2012., p. 31-51.

CALABRESE, Omar. A idade neobarroca. Lisboa: Edições 70, 1999.

CARLÓN, Mario. Repensando os debates anglo-saxões e latino-americanos sobre o "Fim da Televisão". In: CARLÓN, Mario \& FECHINI, Yvana. (orgs.). O fim da televisão. Rio de Janeiro: Confraria do Vento, 2014.

COUTINHO, Eduardo; ZANGRANDI, Raquel Freire; ALMEIDA, Bia. Jogo de cena. [S.l.]: Video Filmes, 2008. 1 DVD vídeo (aprox. 107 min)

FAUSTO NETO, Antônio. Narratividades jornalísticas no ambiente de circulação. In: PICCININ, Fabiana; SOSTER, Demétrio de Azeredo (Orgs). Narrativas comunicacionais complexificadas. Santa Cruz do Sul: EDUNISC, 2012, p. $45-67$.

FIGUEIREDO, Vera Follain de. Narrativas migrantes: literatura, roteiro e cinema. Rio de Janeiro: PUC - RJ, 2010.

FORSTER, E. M. Aspectos do romance. Porto Alegre: Globo, 1969.

GRANDIM, Anabela. A televisão no seu labirinto. In: SERRA, Paulo; SÁ, Sónia \& SOUZA FILHO, Washington. A televisão ubíqua.Covilhã: Livros LabCom Books, 2015. 305 p. Disponível em http://www.livroslabcom.ubi.pt/book/136\#sthash.YeKXteFe.dpuf. Acesso mai 2018.

JAGUARIBE, Beatriz. O choque do real: estética, mídia e cultura. Rio de Janeiro: Rocco, 2007.

JENKINS, H. A cultura da convergência. São Paulo: Aleph, 2009.

LIPOVETSKY, Gilles \& SERROY, Jean. A tela global. Mídias culturais e cinema na era da hipermodernidade. Porto Alegre: Sulina, 2009.

LYOTARD, Jean François. A condição pós-moderna. 8. ed. Rio de Janeiro: J. Olympio, 2004.

MACHADO, Arlindo; VELÉZ, Marta Lucía. Fim da televisão? In: CARLÓN, Mario \& FECHINE, Yvana. O fim da televisão. Rio de Janeiro/Recife: Confraria dos Ventos Editora UFPE, 2014.

MARGATO, Izabel e GOMES, Renato. Novos realismos. Belo Horizonte, 2013.

MOTTA, Luiz Gonzaga. Análise crítica da narrativa. Brasília: Ed. Da UnB, 2013.

MURRAY, Janet Horowitz. Hamlet no Holodeck: o futuro da narrativa no ciberespaço. São Paulo: Ed. UNESP, 2003.

MUSSO, Pierre. A filosofia da rede. In: PARENTE, André (Org.). Tramas da rede: novas dimensões filosóficas, estéticas e políticas da comunicação. Porto Alegre: Sulina, 2004.

PARENTE, André (Org.). Tramas da rede: novas dimensões filosóficas, estéticas e políticas da comunicação. Porto Alegre: Sulina, 2004.

PICCININ, Fabiana. O "complexo" exercício de narrar e os formatos múltiplos: Para 
pensar a narrativa no contemporâneo. In: PICCININ, Fabiana; SOSTER, Demétrio de Azeredo (Org.). Narrativas comunicacionais complexificadas. Santa Cruz do Sul: EDUNISC, 2012.

PICCININ, Fabiana. Narrativas de um real autenticado: notas sobre a grande reportagem na TV contemporânea. In: PORCELLO, Flávio Antonio Camargo; PEREIRA JÚNIOR, Alfredo Eurico Vizeu; COUTINHO, Iluska (Org.). \#telejornalismo: nas ruas e nas telas. Florianópolis: Insular, 2013.

PICCININ, Fabiana. Narrativas audiovisuais no contemporâneo: pensando as estratégias narrativas das séries televisivas. In: PICCININ, Fabiana, SOSTER, Demétrio de Azeredo. (orgs.). Narrativas do ver, do ouvir e do pensar. Santa Cruz do Sul: Catarse, 2016. 200 p. Disponível em http://editoracatarse.com.br/site/wp-content/uploads/2016/o8/Narrativas_do_ver_do_ouvir_do_pensar_e-book.pdf. Acesso em: 11 abr de 2018.

PICCININ, Fabiana; ETGES, Ananda. O eu que narra, que sente e que diz como são feitas as notícias: Análise da atorização em " Profissão Repórter ». In: PICCININ, Fabiana; SOSTER, Demétrio de Azeredo. Narrativas Comunicacionais Complexificadas 2. Santa Cruz do Sul: Edunisc, 2014, p. 321 - 346.

RUIZ, Castor M. M. Os paradoxos do imaginário. São Leopoldo: UNISINOS, 2003.

SACRAMENTO, Paulo; STEINBERG, Gustavo. O prisioneiro da grade de ferro: auto-retratos. [S.l.]: Califórnia Filmes, 2004. 1 DVD vídeo (124 min).

SANTAELLA, Lúcia. Linguagens líquidas na era da mobilidade. São Paulo: Paulus, 2007.

SANTIAGO, Silviano. Nas malhas da letra: ensaios. Rio de Janeiro: Rocco, 2002.

SCHOLES, Robert; KELLOGG, Robert L. A natureza da narrativa. São Paulo: McGraw-Hill do Brasil, 1977.

SCOLARI, Carlos. Thisistheend: As intermináveis discussões sobre o fim da televisão. In: CARLÓN, Mario \& FECHINE, Yvana. O fim da televisão. Rio de Janeiro/Recife: Confraria dos Ventos Editora UFPE, 2014.

STEINDORFF, Gabriel. Além de um castelo de cartas: a metaficção na série House of cards. Dissertação (Mestrado) - Universidade de Santa Cruz do Sul, 2015. Disponível em http://hdl.handle.net/11624/808.Acesso em: 28 abr 2018.

STUBBLEFIELD, William A. Narrative structure in virtual collaborative environments.Albuquerque, 200o. Disponível em: http://wmstubblefield.com/professional/ publications/NarrativeInCVEs.pdf. Acesso em: 28 abr 2018.

TELLERIA, Ana Serrano. LiquidSpheresonUbiquitous. In: SERRA, Paulo; SÁ, Sónia \& SOUZA FILHO, Washington. A televisão ubíqua. Covilhã: Livros LabCom Books, 2015. 305 p. Disponível em http://www.livroslabcom.ubi.pt/book/136\#sthash.YeKXteFe.dpuf. Acesso em jun 2018.

WEISSBERG, Jean-Louis. Paradoxos da teleinformática. In: PARENTE, André(org.). Tramas da rede. Novas dimensões filosóficas, estéticas e políticas da comunicação. Porto Alegre: Sulina: 2010.

ZIZEK, Slavoj. Bem-vindo ao deserto do real!: cinco ensaios sobre o 11 de setembro e datas relacionadas. São Paulo: Boitempo, 2003. 